\title{
STUDENTS' SPECIFIC COMPREHENSION SKILLS IN ENGLISH BASED ON SCHOOL LOCATIONS, GRADES, AND GENDER'
}

\author{
Soni Mirizon \\ Chuzaimah Dahlan Diem \\ Machdalena Vianty \\ Sriwijaya University, Indonesia \\ smirizon@yahoo.com; chuzaidd@gmail.com; vianty.unsri@gmail.com
}

First received: 15 August 2017

Final proof received: 31 January 2018

\begin{abstract}
Having good English proficiency is a necessity in the $21^{\text {st }}$ century and students' comprehension skills must be identified before any teaching is done. Studies that investigate students' comprehension skills have been conducted over years but the one related to students' specific comprehension skills in terms of their school locations, grade levels, and gender has not been much discussed. This study aims to investigating 355 junior high school students' specific comprehension skills as measured by 18 assessments of Warncke Informal Comprehension Assessment (WICA) Instruments (Warncke \& Shipman, 1984) based on their school locations (City-based District-CBD, the district which has all levels of education-ALED, and underprivileged-based district-UBD) of Palembang City, grade levels $\left(7^{\text {th }}, 8^{\text {th }}, 9^{\text {th }}\right)$ and gender in a developing country context. The findings show that students' comprehension achievement is in average level with those from CBD neighborhood have better mean score than those from the other two locations respectively and higher graders have higher achievements. In terms of gender, females' achievement is better than that of males. While the highest students' achievements are on multiple meanings and context and details, the lowest one is on affixes, and the most influential factors on comprehension are school locations and grades. These results lead to the conclusion that students' comprehension should be enhanced and good school environment provided. It also suggests that the degree of difficulty of the materials match students' grade-level and students be taught using more innovating strategies to achieve the best comprehension and eventually applicable outcome.
\end{abstract}

Keywords: comprehension skills; school location; grade level; gender

The status of English as a global language has been pointed out by Graddol (2000) who claims, "English would enjoy a special position in the multilingual society" (p. 63) including Indonesia. It is spoken worldwide that according to Pennycook (1994), "the rough calculation regarding the number of speakers of English worldwide between 700 million and one billion covering native speakers of English, speakers of English as a second (or intra-national) language, and speakers of English as a foreign (or international) language" (pp. 7-8). The importance of English has especially been highlighted by Kachru (1986) who uses the analogy that knowing English is like having the Aladdin's lamp; once it opens, the roads to international business, technology, science, and travel are all opened. In line with this, Vacca, Vacca, and Mraz (2014) also state that being good at English will make it easier for students to learn other academic subjects, especially in this global era. This is probably more true for Indonesian students who have to start learning English as a foreign language from their junior high schools and more importantly, Indonesia has been involved in the ASEAN Economic Community (AEC) since 2015.

In Indonesia, English is taught as a compulsory subject for the secondary school students, starting from grade 7 to grade 12. The aims of learning English are outlined by the government in the curriculum and based on the Indonesian Government Regulation No. 58, year 2014 (Department of Education and Culture, 2014), and the aim of teaching English subject in junior high school is to develop students' potentials in order to have communicative competence in the interpersonal, transactional, and functional discourses using any kinds of texts both in oral and written English language. This communicative competence could be accomplished by using the elements of language which are accurate and acceptable based on kinds of factual and procedural knowledge, and instilling values of moral characters of the nation in the context of life within the home, school, and larger community.

In order to have good communicative competence, students need to be able to produce information either spoken or written. They are required to have good reading abilities because a major goal of reading is comprehension. In other words, comprehension is the purpose of reading, and reading without comprehension is not reading but only sounding words (Cooper, 1993). In short, 
having good comprehension is required if a reader wants to understand text well. Comprehending text might not be easy to do since Hamra and Satriyana (2010) found that comprehension or meaning is related to word symbols, choice of correct meaning in context, organization of texts and retention of meaning in addition to one's ability to grasp meaning of words, phrases, sentences, or long selections. Also, comprehension requires accurate word decoding and recognition; that is why decoding ability and word recognition skills determine comprehension ability (Landi, 2010).

According to Cain and Oakhill (2003), if someone wants to become an independent reader, he or she must be able to decode the individual word and comprehend the text. This is due to the close relationship between word decoding and comprehension. Furthermore, Cain and Oakhill (2003, p. 313) argue, "when decoding and reading comprehension difficulties are concomitant, problems with understanding can arise because laboured word decoding leaves the reader with insufficient processing capacity to compute the relations between successive words, phrases, sentences to construct a coherent and meaningful representation of the text."

Comprehension skills are necessary to understand both written and spoken language (Burgoyne, Kelly, Whiteley, \& Spooner, 2009). If a reader is unable to comprehend the text read, he or she will miss the information. Habibian and Roslan (2014) argued that lack of reading comprehension skill leads to the failure in understanding information and ultimately result in poor academic performance. This is because comprehension is an interrelated skill involving a number of processes at several different levels. Consequently difficulties in any one of several component skills may contribute to comprehension failure (August, Francis, Hsu, \& Snow, 2006; Cain \& Oakhill, 2006a).

Assessing comprehension of both written and spoken text may therefore identify whether comprehension difficulties reflect a general language comprehension problem, or difficulties related to specific comprehension skills (Cain \& Oakhill, 2006b). Difficulties with comprehension require specific and targeted support (Burgoyne, Kelly, Whiteley \& Spooner, 2009). Therefore, students' specific comprehensions need to be assessed and identified before any teaching and learning process takes place because according to Widdowson (1990) learners do not easily infer knowledge of the language from the input they receive without the English teacher's awareness and also of their own; hence an effort to attract students' attention to the linguistic forms by identifying their strengths and weaknesses is necessary in language learning and therefore becomes the focus in this present study.

Unfortunately, although English literacy is a burning issue in the 21 st century, to cope with the flood of information, the data from international measures indicate that Indonesian people literacy, even in Indonesian language is still weak. World's Most Literate Nations (WMLN, 2016) rank Indonesia in the $60^{\text {th }}$ rank out of 61 countries. UNESCO Institute for Statistics (2015) also recorded that there are still 331,045 illiterate people aged 15-24, and 11,254,788 illiterate people aged 15 years and older in Indonesia. Furthermore, UNDP (2013) reported that Indonesian adult literacy is in the 88th of 180 countries and in the $108^{\text {th }}$ rank out of 187 respectively. In addition, in Program for International Student Assessment (PISA) Indonesian students' literacy is also very low, placing Indonesia in the $57^{\text {th }}$ of 65 countries in 2009 and $64^{\text {th }}$ of 65 countries in 2012 (OECD, 2009, 2012).

In particular, when literacy in English is noticed, it is found that Indonesian students' achievement is not that satisfactory. The data from the result of Test of English for International Communication (TOEIC) on Test Takers Worldwide 2015 reveal that Indonesia ranked $43^{\text {rd }}$ out of 46 countries, while in Test of English as a Foreign Language (TOEFL) ITP, Indonesian mean score is 477 (Education Testing Service, 2015). Also, results of English Proficiency Index (EPI) showed that Indonesia's position was $32^{\text {nd }}$ out of 70 countries with mean score 52.91 (Education First, 2015). Furthermore, in PIRLS, Indonesian was in the $42^{\text {nd }}$ rank of 45 countries (PIRLS, 2012). Even in smaller scope, Indonesia is in the $8^{\text {th }}$ of 16 countries in Asia. In national scope, results of EPI noted that even English proficiency in Indonesian provinces was moderate, but South Sumatera had low mean score (46.16) (Education First, 2014). This certainly makes sense since there were still around 102,969 illiterate adults in South Sumatera in 2010 (Ministry of Education and Culture, 2012).

Within South Sumatera Province itself, the citizens' English literacy performance is still problematic where teachers' mean score of TOEFL is 485, junior high school students' functional reading score is 36.92 (Diem \& Atmanegara, 2014) and English achievement of senior high school students is 58.51 (Diem \& Lestari, 2016). Furthermore, studies conducted during 2009-2015 show that the average score of reading comprehension of university students in Palembang was also low; the mean score is 59.03 (See Fitriana, 2009; Risa, 2013; Pamuji, 2013; Sartika, 2014; Gumartifa, 2015; Hutagalung, 2015).

The above data indicate that Indonesian people literacy requires serious attention, particularly to those of secondary schools. Helping students focus on the formal aspects of literacy (language) may be possible through focusing on specific comprehension forms or skills as the pedagogical means. As Long (1991, pp. 45-46) explains, focus on form “... overtly draws students' attention to 
linguistic elements as they arise incidentally in lessons whose overriding focus is on meaning or communication". In other words, language learners have to pay attention to forms and at the same time they also focus on meanings. This can take several forms such as giving students explanation about grammatical or lexical elements while doing a communicative activity or asking students questions regarding the linguistic elements (Nowbakht, Moinzadeh, \& Dabaghi, 2015) and in this study we start with assessing students' specific comprehension. Therefore, in learning English as the target language, input enhancement is one of the pedagogical means and the goal of it is to focus learners' attention on language forms and meanings by making the forms more perceptually salient or easily comprehended (Nassaji \& Fotos, 2011).

The aim of this study is to find out the junior high school students' comprehension on specific skills based on their school locations, grade levels, and gender as the basis for giving some English literacy treatments in the near future so that they could be prepared to participate significantly well in their teaching and learning process in this challenging world.

There are some rationales of focusing this current study on school locations, grades, and gender. It seems that school locations influence students' achievement. It is found that students in rural area are placed less importance on specific areas of academic achievement skills (Ley, Nelson, \& Beltyukova, 1996). Rural students display more hesitancy about graduating from high school and going on to college; they place less importance on academics (including English) and homework assignments (Xu, 2009), while urban students performed better than rural students in maths (Alordiah, Akpadaka \& Oviogbodu, 2015). Even students who study in different districts of the same urban area may have different academic achievement.

In terms of grade levels, lower grade levels perform better than higher grade levels (Diem \& Atmanegara, 2014), while logically, it should be the other way around.

Then, in relation to gender, previous studies reported inconsistent findings. Some studies indicate that males perform better than females, such as in maths, while females are better than males in reading literacy (OECD, 2011); boys love adventurous and humorous stories, while girls do not (Nilsen, Blasinggame, \& Donelson, 2009). Other studies show that there is a significant difference in reading achievement in terms of gender (Lynn \& Mikk, 2009), while there is no difference between males and females in English achievement but male students are better in vocal expression (Diem \& Lestari, 2016). These findings indicate that there is no such similar view that males are better than females or vice versa while we believe that either one is better than the other. Thus, involving these three variables - school locations, grades, and gender are crucial in this current study.

\section{METHOD}

\section{Participants and Data Collection}

The subjects of this study are 355 junior high school students of different public schools in Palembang City, South Sumatera Province, Indonesia. They represent three locations or neighbourhoods consisting of one school from City-based District (CBD), two schools from All Levels of Education District (ALED), and one school from Underprivileged-based District (UBD) neighbourhoods. All of the students from grades 7 , 8 , and 9 were chosen randomly and proportionally based on the number of the population and of gender. In addition, the selection of the students also considered the students English proficiency as measured by the schools. In other words, the selection of the participants of the three grades applied the stratified random sampling in which gender and English achievement within each grade were considered. They were given informal comprehension assessments to find out about their achievements of certain aspects of English comprehension.

The instruments used for data collection are ready made called Warncke Informal Comprehension Assessment (WICA) Instruments (Warncke \& Shipman, 1984, pp. 108-143) consisting of 18 assessments, namely: compound words, contractions, base word inflections, affixes, synonyms, antonyms, multiple meanings and context, details, sequence, cause and effect, main idea, following directions, inferred details, inferred sequence, inferred cause and effect, inferred main idea, fact and opinion, and verifying accuracy. Every assessment basically covers three categories or levels of achievements-level A (low), level B (average), and level $\mathrm{C}$ (high) except assessment \#4 (affixes) has no level A; assessment \#12 (following directions) has no levels but consists of part one and part two; assessments \#13 (inferred details), \#15 (inferred cause and effect), \#16 (inferred main idea), \#17 (fact and opinion), and \#18 (verifying accuracy) have no level C. Altogether there are 268 items.

Table 1 presents an example of the assessment items in multiple meaning and context. Oral explanation on how to do the test for every assessment was given before students did the test. Every item scores 1 if it is correctly answered by the student and zero if it is incorrectly answered. The range of achievements are divided into three categories, such as $0-60$ (below average), 61-75 (average), and 76-100 (above average).

\section{Data Analyses}

Students' scores obtained from this research are 
described using Descriptive Statistics. Then to see the contribution of each aspect of the comprehension skills to the total comprehension, regression analyses were used. Finally, to see if any of the three variables (students' school locations, grade levels, and gender) influences students' comprehension achievements, 2-tailed ANOVA was used.

\section{FINDINGS AND DISCUSSION \\ Findings}

Descriptive Statistics

The data gathered from the WICA Instruments were analyzed descriptively. As shown in Table 2, the total mean score of the students' comprehension achievement is 67.53 (average) with higher graders having higher scores (mean of $9^{\text {th }}$ grade $=75.46$ (above average); mean of $8^{\text {th }}$ grade $=65.20$ (average); and mean of $7^{\text {th }}$ grade $=61.97$ (average).

The results of the data analysis on the students' comprehension skills based on school locations and grades reveal that the students from CBD school are better achievers $($ mean $=80.55)$ than those from the other two locations (mean $=65.88$ and 56.17 respectively). In terms of gender, females (mean = $68.03)$ are better than males $($ mean $=67.04)$. See Table 3.

\section{Students' Comprehension Sub-Skills}

The descriptive analysis was also done to see the mean scores for each of the 18 comprehension skills. The results of the analysis as presented in Table 4 show that the highest mean scores are on multiple meanings and contexts (18.61) and details (18.32).

Table 1. An example of Assessment 7: Multiple meanings and context (Warncke \& Shipman, 1984, pp. 114)

\begin{tabular}{|c|c|c|}
\hline Level A & Level B & Level C \\
\hline $\begin{array}{l}\text { 1a. I like my new watch. } \\
(\ldots) \\
\text { 1b. Watch me play ball. } \\
\text { (...) } \\
\text { A. keep safe } \\
\text { B. timekeeper } \\
\text { C. look at }\end{array}$ & $\begin{array}{l}\text { 1a. Be sure to match your sock. } \\
\text { (...) } \\
\text { 1b. Never play with a match. }(. . .) \\
\text { A. a stick to start fire. } \\
\text { B. a contest } \\
\text { C. put same kinds together }\end{array}$ & $\begin{array}{l}\text { 1a. Be sure to cover your tracks } \\
\text { when you want to hide your } \\
\text { deeds. }(. .) \\
\text { 1b. The snow cover was very deep } \\
\text { in the dead of winter. }(. . .) \\
\text { A. overlay } \\
\text { B. conceal } \\
\text { C. clothe play ball }\end{array}$ \\
\hline $\begin{array}{l}\text { 2a. We sat on the bank to } \\
\text { fish. (...) } \\
\text { 2b. You can bank on me. } \\
\text { (...) } \\
\text { A. keeper of money } \\
\text { B. count on } \\
\text { C. edge of river }\end{array}$ & $\begin{array}{l}\text { 2a. The pilot landed the plane } \\
\text { safely. }(. .) \\
\text { 2b. The pilot light on the stove } \\
\text { went out. (...) } \\
\text { A. guide } \\
\text { B. small flame } \\
\text { C. person driving }\end{array}$ & $\begin{array}{l}\text { 2a. To be sure the boat is fast, tie a } \\
\text { rope from each end to the dock. } \\
\text { (...) } \\
\text { 2b. After the severe and heavy } \\
\text { thunderstorm, the river ran very } \\
\text { fast. (...) } \\
\text { A. swiftly } \\
\text { B. loudly } \\
\text { C. secure }\end{array}$ \\
\hline $\begin{array}{l}\text { 3a. } \frac{\text { Duck under the rope. }}{(\ldots)} \\
\text { 3b. I have a pet duck. (...) } \\
\text { A. a bird } \\
\text { B. bend down } \\
\text { C. begin }\end{array}$ & $\begin{array}{l}\text { 3a. Never strike a friend in anger. } \\
\text { (...) } \\
\text { 3b. The men went on strike for } \\
\text { money. }(. . .) \\
\text { A. nibble } \\
\text { B. hit } \\
\text { C. stop work }\end{array}$ & $\begin{array}{l}\text { 3a. The insurance agent came to } \\
\text { talk to us about five insurance } \\
\text { rope. (...) } \\
\text { 3b. Mother bought me a new } \\
\text { cleaning agent for one of her } \\
\text { special projects. (...) } \\
\text { A. product } \\
\text { B. person } \\
\text { C. result }\end{array}$ \\
\hline
\end{tabular}

\section{Students' Comprehension Sub-Skills}

The descriptive analysis was also done to see the mean scores for each of the 18 comprehension skills. The results of the analysis as presented in
Table 4 show that the highest mean scores are on multiple meanings and contexts (18.61) and details (18.32).

Table 2. Junior High School Students' Comprehension Based on School Locations and Grades (N=355)

\begin{tabular}{|c|c|c|c|c|c|c|c|c|c|c|}
\hline \multirow{3}{*}{ Grade } & \multicolumn{9}{|c|}{ School Locations } & \multirow{3}{*}{$\begin{array}{l}\text { Total } \\
\text { Mean }\end{array}$} \\
\hline & \multicolumn{3}{|c|}{ CBD } & \multicolumn{3}{|c|}{ ALED } & \multicolumn{3}{|c|}{ UBD } & \\
\hline & $\mathbf{N}$ & $\%$ & Mean & $\mathbf{N}$ & $\%$ & Mean & $\mathbf{N}$ & $\%$ & Mean & \\
\hline 7 & 30 & 33 & 78.89 & 58 & 32 & 62.95 & 30 & 26 & 44.07 & 61.97 \\
\hline 8 & 27 & 33 & 80.56 & 59 & 32 & 62.54 & 30 & 31 & 52.52 & 65.26 \\
\hline 9 & 31 & 34 & 82.29 & 60 & 36 & 72.15 & 30 & 43 & 71.94 & 75.46 \\
\hline Total & 88 & 100 & 80.5 & 177 & 100 & 65.8 & 90 & 100 & 56.1 & 67.53 \\
\hline
\end{tabular}


Table 3. Junior High School Students' Comprehension Based on School Locations and Gender (N=355)

\begin{tabular}{ccccccccc}
\hline \multirow{2}{*}{$\begin{array}{c}\text { School } \\
\text { Location }\end{array}$} & \multirow{2}{*}{ N Total } & \multicolumn{4}{c}{ Male } & \multicolumn{2}{c}{ Female } & \multirow{2}{*}{$\begin{array}{c}\text { Mean Total } \\
\text { Male \& }\end{array}$} \\
\cline { 2 - 8 } & & $\mathbf{N}$ & \% & Mean Score & N & \% & Mean Score & Female \\
\hline CBD & 88 & 44 & 50.0 & 80.13 & 44 & 50.0 & 81.07 & 80.55 \\
ALED & 177 & 75 & 42.4 & 65.53 & 102 & 57.6 & 66.23 & 65.88 \\
UBD & 90 & 45 & 50.0 & 55.46 & 45 & 50.0 & 56.89 & 56.17 \\
Total & 355 & 164 & 47.47 & 67.04 & 191 & 52.53 & 68.03 & 67.53 \\
\hline
\end{tabular}

Table 4. Mean Scores of Junior High School Students' Comprehension Skill Based on Aspects of Comprehension Skills

\begin{tabular}{clcc}
\hline No. & \multicolumn{1}{c}{ Model } & Mean Scores & Std. Deviation \\
\hline 1 & Multiple Meaning and Context & 18.61 & 6.175 \\
2 & Detail & 18.32 & 5.823 \\
3 & Contractions & 14.27 & 2.305 \\
4 & Following Direction & 13.18 & 5.549 \\
5 & Base-Word Inflection & 11.93 & 2.559 \\
6 & Inferred Sequence & 10.79 & 2.059 \\
7 & Sequence & 10.21 & 2.809 \\
8 & Cause and Effect & 10.02 & 3.478 \\
9 & Main Idea & 9.10 & 1.658 \\
10 & Synonym & 8.87 & 3.483 \\
11 & Antonym & 8.52 & 3.421 \\
12 & Compound Words & 8.37 & 2.783 \\
13 & Verifying Accuracy & 7.16 & 38.165 \\
14 & Facts or Opinions & 6.97 & 2.281 \\
15 & Inferred Main Idea & 6.31 & 2.134 \\
16 & Inferred Details & 5.94 & 1.892 \\
17 & Inferred Cause and Effect & 5.73 & 2.120 \\
18 & Affixes & 5.54 & 2.816 \\
\hline
\end{tabular}

It also shows that the students' lowest achievement of comprehension is on affixes (Mean $=5.54)$ and since most of the other aspects of comprehension skills are still poorly comprehended by the students, it can be concluded that the students need to be exposed to these specific comprehension skills.

However, when each skill is analyzed to see its contribution towards the whole comprehension (total), only multiple meanings and context contributed the highest $(72 \%)$. The rest is contributed by following directions $(12.2 \%)$, details $(5.9 \%)$, antonym $(3.1 \%)$, cause and effect $(1.7 \%)$, and synonyms $(1.3 \%)$. The other 12 subskills contributed only for $3.8 \%$. This means that although some of them have higher mean scores, it does not guarantee that they contribute to students' comprehension as a whole (see Table 5).

\section{Statistical Analyses}

Following some procedures, the data of this research are analyzed by using linear multiple regression analysis with SPSS in which independent variables are Locations, Grades, and Gender and the dependent variable is Comprehension Skills. In the linear regression model, there are several assumptions that should be fulfilled in order to have efficient estimated results, that is, no digression happens and the information obtained matches the real condition. This also aims at presenting the Best Linear Unbiased Estimated (BLUE) characteristic of regression model. Therefore, the classical assumptions used are normality test, linearity test, multicolinearity test, autocorrelation test, and heterocedasticity test.

It terms of normality, it is found that the value of Asymp. Sig. is 0.998 higher than 0.05. Therefore, it can be concluded that the data is normally distributed. The result of linearity shows that the $\mathrm{R}^{2}$ value is 0.004 (observed $\mathrm{N}=355$ ). It shows that the size of $c^{2}$ obtained $=355 \times 0.004=14.2$. Using significant level of 0.05 the value is compared to $c^{2}$ table with $\mathrm{df}=(\mathrm{n}-\mathrm{k})=355-3=352$ with the $\mathrm{c}^{2}$ table $=341.395$. Therefore, if the $\mathrm{c}^{2}$ obtained is less than $\mathrm{c}^{2}$ table, the right model to be used is linear model. In terms of multicolinierity test, the tolerance value of all independent variables $>0.10$ and VIF value of all independent variables $<10.00$. Thus, it can be conluded that there is no multicolinearity. The result of autocorrelation test, the value of Durbin Watson is between -2 to +2 . This means there is no autocorrelation. Finally, in terms of heterocedasticity test, with the $\mathrm{R}^{2}=0.060$ and the observed $\mathrm{N}=355$, the size of chi-square obtained is $355 \times 0.060=21.3$. When this value is compared with the chi-square table with $\mathrm{df}=(\mathrm{n}-\mathrm{k})=355-7=$ 347 with level of significance $=0.05$, the chi-square table $=341.395$. Since chi-square obtained value is 
less than the chi-square table, then the heterocedasticity in this model is refused.

Substructure Analyses

Based on substructure analyses, it is found that the
$\mathrm{R}$ Square is 0.498. It means that the size of influence of school locations, grades and gender on comprehension skills simultaneously is $49.8 \%$. The feasibility of the regression model is presented in Table 6.

Table 5. Contribution of Each Comprehension Skill to Comprehension Skill Achievement

\begin{tabular}{|c|c|c|c|}
\hline Model & R Square & $\begin{array}{l}\text { R Square } \\
\text { Changed } \\
\end{array}$ & $\begin{array}{c}\text { Sig. F } \\
\text { Change }\end{array}$ \\
\hline Multiple Meaning and Context & .720 & .720 & .000 \\
\hline Multiple Meaning and Context, Following Direction & .842 & .122 & .000 \\
\hline Multiple Meaning and Context, Following Direction, Details & .901 & .059 & .000 \\
\hline Multiple Meaning and Context, Following Direction, Details, Antonym & .933 & .031 & .000 \\
\hline $\begin{array}{l}\text { Multiple Meaning and Context, Following Direction, Details, Antonym, } \\
\text { Cause and Effect }\end{array}$ & .949 & .017 & .000 \\
\hline $\begin{array}{l}\text { Multiple Meaning and Context, Following Direction, Details, Antonym, } \\
\text { Cause and Effect, Synonym }\end{array}$ & .962 & .013 & .000 \\
\hline $\begin{array}{l}\text { Multiple Meaning and Context, Following Direction, Details, Antonym, } \\
\text { Cause and Effect, Synonym, Affixes }\end{array}$ & .969 & .007 & .000 \\
\hline $\begin{array}{l}\text { Multiple Meaning and Context, Following Direction, Details, Antonym, } \\
\text { Cause and Effect, Synonym, Affixes, Inferred Sequence }\end{array}$ & .974 & .005 & .000 \\
\hline $\begin{array}{l}\text { Multiple Meaning and Context, Following Direction, Details, Antonym, } \\
\text { Cause and Effect, Synonym, Affixes, Inferred Sequence, Fact or Opinion }\end{array}$ & .979 & .005 & .000 \\
\hline $\begin{array}{l}\text { Multiple Meaning and Context, Following Direction, Details, Antonym, } \\
\text { Cause and Effect, Synonym, Affixes, Inferred Sequence, Fact or Opinion, } \\
\text { Contraction }\end{array}$ & .982 & .003 & .000 \\
\hline $\begin{array}{l}\text { Multiple Meaning and Context, Following Direction, Details, Antonym, } \\
\text { Cause and Effect, Synonym, Affixes, Inferred Sequence, Fact or Opinion, } \\
\text { Contraction, Inferred Main Idea }\end{array}$ & .985 & .003 & .000 \\
\hline $\begin{array}{l}\text { Multiple Meaning and Context, Following Direction, Details, Antonym, } \\
\text { Cause and Effect, Synonym, Affixes, Inferred Sequence, Fact or Opinion, } \\
\text { Contraction, Inferred Main Idea, Sequence }\end{array}$ & .989 & .003 & .000 \\
\hline $\begin{array}{l}\text { Multiple Meaning and Context, Following Direction, Details, Antonym, } \\
\text { Cause and Effect, Synonym, Affixes, Inferred Sequence, Fact or Opinion, } \\
\text { Contraction, Inferred Main Idea, Sequence, Compound }\end{array}$ & .992 & .003 & .000 \\
\hline $\begin{array}{l}\text { Multiple Meaning and Context, Following Direction, Details, Antonym, } \\
\text { Cause and Effect, Synonym, Affixes, Inferred Sequence, Fact or Opinion, } \\
\text { Contraction, Inferred Main Idea, Sequence, Compound, Inferred Details }\end{array}$ & .994 & .002 & .000 \\
\hline $\begin{array}{l}\text { Multiple Meaning and Context, Following Direction, Details, Antonym, } \\
\text { Cause and Effect, Synonym, Affixes, Inferred Sequence, Fact or Opinion, } \\
\text { Contraction, Inferred Main Idea, Sequence, Compound, Inferred Details, } \\
\text { Verifying Accuracy }\end{array}$ & .995 & .002 & .000 \\
\hline $\begin{array}{l}\text { Multiple Meaning and Context, Following Direction, Details, Antonym, } \\
\text { Cause and Effect, Synonym, Affixes, Inferred Sequence, Fact or Opinion, } \\
\text { Contraction, Inferred Main Idea, Sequence, Compound, Inferred Details, } \\
\text { Verifying Accuracy, Main Idea }\end{array}$ & .997 & .001 & .000 \\
\hline $\begin{array}{l}\text { Multiple Meaning and Context, Following Direction, Details, Antonym, } \\
\text { Cause and Effect, Synonym, Affixes, Inferred Sequence, Fact or Opinion, } \\
\text { Contraction, Inferred Main Idea, Sequence, Compound, Inferred Details, } \\
\text { Verifying Accuracy, Main Idea, Inferred Cause and Effect }\end{array}$ & .998 & .001 & .000 \\
\hline $\begin{array}{l}\text { Multiple Meaning and Context, Following Direction, Details, Antonym, } \\
\text { Cause and Effect, Synonym, Affixes, Inferred Sequence, Fact or Opinion, } \\
\text { Contraction, Inferred Main Idea, Sequence, Compound, Inferred Details, } \\
\text { Verifying Accuracy, Main Idea, Inferred Cause and Effect, Base-Word } \\
\text { Inflections }\end{array}$ & .998 & .000 & .000 \\
\hline
\end{tabular}

While the F-table with df $1=(\mathrm{k}-1)=3-1=2$ and $\mathrm{df} 2=(\mathrm{n}-\mathrm{k})=355-3=352$, the value of $\mathrm{F}-$ obtained $=116.128$. It is bigger than the F-table $=$ 3.04. Therefore, the regression model is appropriate to be used (feasible and accurate) with the level of significance $0.000<\alpha=0.05$. Table 7 presents the analysis to see the degree of influence of locations, grades, and gender on students' comprehension skills.
Tabel 6. F-value and Level of Sig.of Locations, Grades and Gender on Comprehension Skills

\begin{tabular}{ccc}
\hline Model & F & Sig. \\
\hline Regression Residual Total & 116.128 & 0.000 \\
\hline
\end{tabular}

In this case, the model used to analyse the above results is as follows.

Comprehension $=-32.595$ Locations +16.653

Grades + 2.137 Gender + 192.526 
Tabel 7. Partial Influence of Locations, Grades, and Gender on Students' Comprehension Skills

\begin{tabular}{lcrrr}
\hline \multirow{2}{*}{ Model } & Unstandardized Coefficients & \multirow{2}{*}{ T } & \multirow{2}{*}{ Sig. } \\
\cline { 2 - 2 } & \multicolumn{1}{c}{ Beta } & & \\
\hline (Constant) & 192.526 & & 35.587 & 0.000 \\
Locations & -32.595 & -16.015 & 0.000 \\
Grades & 16.653 & & 9.481 & 0.000 \\
Gender & 2.137 & 0.739 & 0.460 \\
\hline
\end{tabular}

Based on the analyses, it is found that for the locations the t-obtained $=-16.015>(-)$ t-table $=$ 1.97190 with significant level of $0.000<\alpha=0.05$. This means that there is an influence of locations on comprehension skills; for the grades, the t-obtained $=9.481>$ t-table $=1.97190$ with significant level of $0.000<\alpha=0.05$. This means that there is also an influence of grades on students' comprehension skills. Finally, for the gender, it is found that the tobtained $=0.739<$ t-table $=1.97190$ with significant level of $0.460>\alpha=0.05$. This means that there is no influence of gender on students' comprehension skills.

\section{Discussion}

The findings of this study show that multiple meanings and context aspect has the highest mean score of students' comprehension skill. This might be due to the kinds of words meaning to guess. When the test items of multiple meaning in context aspect are noticed, most of the words meaning to guess from context are verbs and nouns which are relatively easier than other word categories (see Table 1). This is in line with what $\mathrm{Na}$ and Nation (1985) reported that the meaning of verbs and nouns are easier to guess than adverbs and adjectives in guessing vocabulary in context. When the contribution of each skill is analysed, it is also found that multiple meanings and context aspect gives the biggest contribution (72\%) towards the whole comprehension (total). Why multiple meaning and context aspect gives the biggest contribution towards the whole comprehension skill is because generally students could comprehend meaning relatively easy if the situation or context of a given text or story is provided. When they get stuck with the meaning of a certain word or a group of words in the text that they are unfamiliar with, they can guess its meaning from the context provided in the text, as Ciftci and Uster (2009) point out that the meaning of words reflects the context in which it is used.

The findings of this study also indicate that school locations seem to play important roles in students' comprehension achievements. It is assumed that the farther the location of the schools from the center of the business and government activities is, the lower the students' English comprehension would be. It is likely due to the facts that many English courses available in Palembang are located in the CBD areas. Therefore, in terms of accessibility, such as transportation, taking an extra English course lesson after school will not be a problem for the students. In other words, it is an advantage for the students whose schools are located in the CBD. For the schools located in this area, information from Education Regional Office of Palembang, for example, is also easy to access. In addition to the easy access to transportation and information, the internet connection, which is also supported by availability of electricity in the CBD area is much better compared to the other locations.

For the schools located in the ALED area, although the internet connection is available, there are often blackouts. The worst condition is experienced by the schools from the UBD area. For example, the school involved in this study which is located in the UBD area, is not supported by a good internet connection. This has confirmed the fact that the location of schools plays a very significant role in students' learning.

Previous studies show that school location affects student academic achievement. Students whose schools are located in urban areas had better academic achievement than their rural counterparts (Owoeye \& Yara, 2011; Xu, 2009). It is also reported that there is a significant difference in the achievement of students in urban peri-urban areas where students in urban schools manifest more brilliant performance than their rural counterparts (Adepoju, 2001; Ogunleye, 2002; Ndukwu, 2002; Odinko, 2002, and Warwick, 1992). Even though these studies only compare between school location in rural and urban areas in general, they portray that school location does affect student academic achievement, as has been found in this current study where students studying at school located in CBD perform better than those studying in both ALED and UBD. Specifically, the finding of this current study confirms the fact that the students of these three school locations do show a different comprehension performance although the schools are located within the same area (i.e., urban). This is in accordance with what was reported by Rahmi and Diem (2014) that there was a positive correlation between school environment and students' English achievement.

In terms of grades, it is logical that those who are from higher grades would likely to have higher achievements, that is the higher the grade-level of students, the better their comprehension achievement will be (read Shell, Bruning \& Colvin, 1995; Rafhael \& Au, 2005; Shanahan, 1984; Shanahan \& Lomax, 1986). Although in Indonesia, school students are commonly grouped based on 
their age not on their ability, exposure to English and learning experience that students have received may have an impact on their academic development. Previous studies reported that more exposure of English promotes English language learners' English development (see Gamez, 2015; Dewi, 2017). The findings of this current study showed that when it is compared, students from higher grades have received more exposure of English from teaching and learning activities they experience with the teachers of English than those of in the lower grades. Therefore it is possible for higher graders to have better comprehension achievement than the lower graders.

In relation to gender, several previous studies indicate that female students perform better than their male counterparts in many parts of the world such as in Australia, USA, and China (Rothman, 2002; Dee, 2005; Chiu \& McBride-Chang, 2006), but in this current study, no significant difference found in the students' English comprehension. This is likely due to the process of the intake of students. For Year 6 students who want to further their study at a public junior high school, they have to pass an entry test conducted by the school. In addition, the number of male and female students is not really considered in the intake. The finding of this study which shows that there is no significant difference in the students' English comprehension is also probably due to the accreditation of the school which is somewhat the same. They are all accredited A. This finding is in line with what was found by Diem and Lestari (2016) that in general there is no significant difference between males and females in English subject after they were taught using Literature Circles except for the vocal expression where male students were significantly more expressive than their female counterparts. The finding suggests that gender is not the only factor that may influence students' English comprehension ability.

In addition to students' gender and gradelevels, academic success is greatly influenced by other factors. Findings of some studies show that comprehension is influenced by school environments, such as school location, wellmaintained facilities, cleanliness, comfortable services, well-discipline society, student-teacher relationship, and school climate. Lawrence and Vimala (2012) found out that students from urban area have better achievement than those from rural area. In addition, type of school students attend and peer influence made significant contribution to the students' academic performance (Korir \& Kipkemboi, 2014). A clean and well-maintained school is strongly correlated to higher level of students' achievement, as well (OSSTF/FEESO, 2015). School systems, processes, services provided also have impact on students' achievement (Higgins, Hall, Wall, Woolner, \& McCaughey, 2005).
Adequate learning facilities and good teacherstudents relationship are likely to trigger students to perform well (Usaini \& Abubakar, 2015; Rahmi \& Diem, 2014; Nsa, Offiong, Udo \& Ikot, 2014). School climate such as well-discipline school society also has significant influence on students' academic achievement (Odeh, Oguche \& Ivagher, 2015). It is noticed, most of those characteristics of school environments can be found in schools located in CBD schools in Palembang city. Those schools are certainly situated in the centre of business district. In addition, they are well-equipped with at least standardized facilities for education, clean, and well-maintained. Comfortable services are also provided to the school societies. Last but not least, good teacher-students relationship can also be found in those schools. On the other hand, such environments are relatively found at ALED and hardly available at UBD schools. Considering this fact, it is feasible to claim that CBD schools offer more benefits compared to the other ALED and UBD schools. It is reasonable that students attending CBD schools are likely to perform better than those studying at the other two locations.

\section{CONCLUSION}

There are several factors which play a significant role in students' learning. As shown by the findings of this current study, locations of the schools and grades have made a difference in students' English comprehension skills. It is an advantage for the school located at the CBD area since accessing the information is not a problem. Students from the higher grade level are also benefited from more exposure of English because they devote more time using English both in receptive skills (listening and reading) and productive skills (speaking and writing). These two conditions contribute to students' better achievement in specific comprehension skills in English.

Regardless of where students go to schools, either in CBD, ALED, or UBD area and their grades levels $\left(7^{\text {th }}, 8^{\text {th }}, 9^{\text {th }}\right)$, it is a challenge for the teachers to make all students learn equally well. Therefore, one thing proposed to the schools is that students' comprehension should be enhanced and good school environment provided so that they could be prepared to participate significantly well in their teaching and learning process. One of the ways is through implementing various innovating teaching strategies using multiple genres with different readability levels of materials. In this case, the degree of difficulty of the materials should match students' grade-level to achieve the best comprehension and eventually applicable outcome.

\section{REFERENCES}

Adepoju, T. (2001). Location factors as correlates of private and academic performance of 
secondary schools in Oyo state. A Proposal presented at the higher students. Joint Staff Seminar Department of Teacher Education, University of Ibadan, Ibadan.

Alordiah, C.O., Akpadaka, G., \& Oviogbodu, C.O. (2015). The influence of gender, school location and Socio-Economic status on students' academic achievement in mathematics. Journal of Education and Practice, 6(17), 130-136

August, D., Francis, D. J., Hsu, H. Y. A., \& Snow, C. E. (2006). Assessing reading comprehension in bilinguals. The Elementary School Journal, 107(2), 221-238.

Burgoyne, K., Kelly, J. M., Whiteney, H. E., \& Spooner, A. (2009). The comprehension skillsof children learning English as an additional language. British Journal of Educational Psychology, 79, 735-747.

Cain, K., \& Oakhill, J. V. (2003). Reading compression difficulties. In Nunes, T., \& Bryant, P. (eds.). Handbook of Children Literacy. Dordrecht: Kluwer Academic Publishers.

Cain, K., \& Oakhill, J. V. (2006a). Profiles of children with specific reading comprehension difficulties. British Journal of Educational Psychology, 76, 683-696.

Cain, K., \& Oakhill, J. V. (2006b). Assessment matters: Issues in the measurement of reading comprehension. British Journal of Educational Psychology, 76, 697-708.

Chui, M. M., \& McBride-Chang, C. (2006). Gender, context, and reading: A comparison of students in 43 countries (Research Report: Chinese University of Hong Kong.

Ciftci, H., \& Uster, S. (2009). A comparative analysis of teaching vocabulary on context and by definition. Procedia Social and Behavior Sciences 1, 1568-1572.

Cooper, J. D. (1993). Literacy: Helping children construct meaning ( $2^{\text {nd }}$ ed.). Boston, MA: Houghton Mifflin Company.

Dee, T. S. (2005). Teachers and the gender gaps in studenta achievement. NBER Working Paper No. 11660 Cambridge, MA: National Bureau of Economic Research.

Department of Education and Culture. (2014). The Indonesian Government Regulation No. 58, year 2014. Jakarta: The Department of Education and Culture.

Dewi, I. I. (2017). Evaluating students' English ability in comprehending metaphors and its correlation to English proficiency. Advanced Science Letters, 23(1), 248-251.

Diem, C. D., \& Atmanegara, Y. (2014). Cultivating children's reading habits and : Literacy learning enhancement in the digitalization era. International Journal of Innovative Social \& Science Education Research, 3(1), 1-11.
Diem, C. D., \& Lestari, P. (2016). Interaction effects of LCS and gender on tenth graders' English achievements. A paper presented at the Fourth 21st Century Academic Forum, at Harvard, MA, 19-22 March.

Education First. (2014). EF English proficiency index. Retrieved from http://www.ef. Com/wwpt/epi/regions/asia/Indonesia/

Education First. (2015). EPI the largest world's largest ranking of countries by English skill: Indonesia. Retrieved from http://www.ef. co.id/epi/spotlights/asia/Indonesia/

Education Testing Service (ETS). (2015). 2015 Report on test taker worldwide: The TOEIC listening and reading test. Retrieved from https://www.ets.org/s/toeic/pdf/ ww_data_report_unlweb.pdf.

Fitriana. (2009). The correlation among students' idiom understanding,listening, and reading comprehension in teaching training and education faculty of Sriwijaya University (Unpublished Magister Thesis). Sriwijaya University, Palembang, Sumatera Selatan.

Gamez, P. B. (2015). Classroom-based English exposure and English language learners' expressive language skills. Early Childhood Research Quarterly, 31, 135-146.

Graddol, D. (2000). The future of English. Retrieved from https://www.google.com /search?q $=$ the + future + of + english $\&$ ie $=$ utf $-8 \&$ oe $=$ utf -8

Gumartifa, A. (2015). The correlation among reading strategies, reading motivation, and reading comprehension achievement of the English education study program of Muhammadiyah University of Palembang (Unpublished Magister Thesis). Sriwijaya University, Palembang, Sumatera Selatan.

Habibian, M., \& Roslan, S. (2014). The relationship between self-efficacy in reading with language proficiency and reading comprehension among ESL learners. Journal of Education and Science, 5(4), 119-126.

Hamra, A., \& Satriyana, E. (2010). Developing a model of teaching reading comprehension for EFL students. TEFLIN Journal, 21(1), 27-40.

Higgins, S., Hall, E., Wall, K., Woolner, P., \& McCaughey, C. (2005). The impacts of school environment: A literature review. The Centre for Learning and Teaching, School of Education, Communication, and Language Science, University of Newcastle Upon Tyne.

Hutagalung, G. U. (2015). The correlation among critical thinking, reading habit, and reading comprehension achievement of English education study program students of Sriwijaya University (Unpublished Magister Thesis). Sriwijaya University, Palembang, Sumatera Selatan.

Kachru, B. J. (1986). The alchemy of English: The spread, functions and models of non-native 
Englishes. New York, NY: Oxford Pergamon Press.

Korir, D. K. \&Kipkemboi, F. (2014). The impact of school environment and peer influences on students' academic performance in Vihiga County, Kenya. International Journal of Humanities and Social Science, 4(5), 240-251.

Landi, N. (2010). An examination of the relationship between reading comprehension, higher-level and lower-level reading sub-skills in adult. Read Writ, 23(6), 701-7017.

Lawrence, A. S. A., \& Vimala, A. (2012). School environment and academic achievement of standard IX students. Journal of Educational and Instructional Studies in the World, 2(3), 210-215.

Ley, J., Nelson, S., \& Beltyukova, S. (1996). Congruence of aspirations of rural youth with expectations held by parents and school staff. Journal of Research in Rural Education, 12(3), 133-141.

Long, M. H. (1991). Focus on form: A design feature in language teaching methodology. Foreign Language Research in Cross-cultural Perspective, 2(1), 39-52.

Lynn, R., \& Mikk, J. (2009). Sex differences in reading achievement. Thames 13(1), 3-13.

Ministry of Education and Culture. (2012). Literacy: Empowerment, development, and peace. Retrieved from http://www.unesco.org/new/fileadmin/MULTI MEDIA/ HW/ED/pdf/Indonesia.pdf.

Na, L., \& Nation, P. (1985). Factors affecting guessing vocabulary in context. RELC Journal, 16(1), 33-42.

Nassaji, H., \& Fotos, S. (2011). Teaching grammar in second language classroom: Integrating form focussed instruction in communicative context. New York, NY: Taylor and Francis.

Ndukwu, P. N. (2002). School and Teacher Factors as Determinants of Classroom Material Resources Utilization in pre-primary Schools in Lagos State. Unpublished Ph.D Thesis.

Nilsen, A. P., Blasingame Jr, J., \& Donelson, K. L. (2009). 2008 Honor List-A Shifting of Paradigms. English Journal, 99(2), 80.

Nowbakht, M., Moinzadeh, A., \& Dabaghi, A. (2015). Effects of massed vs.distribute implicit font on receptive acquisition of L2 vocabulary items. The Journal of Asia TEFL, 12(3), 115147. Retrieved from http://dx.doi.org/10.18823/asiatefl. 2015. 1.2.3.5.115

Nsa, S. O., Offiong, A. A., Udo, M. F., \& Ikot, A. S. (2014). School environmental variables and students academic performance in agricultural science. International Journal of Business and Social Science. 5(8), 163-167.

Odeh. R. C, Oguche, O. A., \& Ivagher, E. D. (2015). Influence of school environment on academic achievement of students in secondary schools in zone A Senatorial District of Benue State, Nigeria. International Journal of Recent Scientific Research, 6(7), 4914-4922.

Odunko, M. N. (2002). Home and School Factors as Determinants of Literacy of Skill Development among Nigeria Pre-primary School Children. Unpublished Ph.D Thesis University of Ibadan, Ibadan.

OECD. (2009). PISA 2009 results: what students know and can do: student performance in reading, mathematics and science (Volume I). OECD, Paris, France.

OECD. (2011). Do boys and girls have different reading habits? in PISA 2009 at a glance. Paris: OEC Publishing. Retrieved from http://www.oecd-ilibrary.org/ docserver/download/9810131ec030.pdf?expire $\mathrm{s}=1479521019 \& \mathrm{id}=\mathrm{id} \&$ accname $=$ guest $\&$ check sum $=28144$ B75E251618F3C594B461D33260 6.

OECD. (2012). PISA 2012 Results in Focus. What 15-year-old know and what they can do with what they know. OECD, Paris, France.

Ogunleye, B. O. (2002). Evaluation of the Environmental Aspects of the Senior Secondary School Chemistry Curriculum in Ibadan, Nigeria. Unpublished Ph.D Thesis University of Ibadan, Ibadan.

OSSTF/FEESO. (2015). Impact of the school environment on student achievement. Education Watch, Issue 5. March 2015.

Owoeye, J. S., \& Yara, P. O. (2011). School location and academic achievement of secondary school in Ekiti Sate, Nigeria. Asian Social Science, 7(5), 170-175.

Pamuji (2013). The correlation among attitude, reading comprehension, and writing achievement of English education study program students of Sriwijaya University (Unpublished Magister Thesis). Sriwijaya University, Palembang, Sumatera Selatan.

Pennycook, A. (1994). The cultural politicsof English as an International language. Harlow, UK: Longman Group Limited.

PIRLS. (2012). PIRLS 2011 International Results in Reading: International Association for the Evaluation of Educational Achievement (IEA). Retrieved from http:// timsandpirls.bc.edu/pirls2011/downloads/P11_ IR_Fullbook.Pdf

Rafhael, T. E., \& Au, K.H. (2005). QAR: Enhancing comprehension and test taking across grades and content areas. The Reading Teacher, 59(3), 206-221.

Rahmi, R. A., \& Diem, C. D. (2014). Junior high school students' perception of classroom environment and their English achievement. International Journal of Applied Linguistics and English Literature, 3(3), 41-47. 
doi:10.7575/aiac.ijalel.v. 3n.3p.41

Risa. (2013). Improving reading and writing skills of students of hospitality industry concentration program of Sriwijaya State Polytechnic through weblog (Unpublished Magister Thesis). Sriwijaya University, Palembang, Sumatera Selatan.

Rothman, S. (2002). Achievement in literacy and numeracy by Australian 14 year-olds, 19751980. Research Report.is-pin'Melbourne, Victoria: Australian Council for Educational Research.

Sartika. (2014). A survey on students' reading attitudes, reading habit and reading comprehension achievement of PGRI University Palembang (Unpublished Magister Thesis). Sriwijaya University, Palembang, Sumatera Selatan.

Shanahan, T. (1984). Nature of the reading-writing relation: An exploratory multivariate analysis. Journal of Educational Psychology, 76, 466477.

Shanahan, T., \& Lomax, R. G. (1986). An analysis and comparison of theoretical models of the reading-writing relationship. Journal of Educational Psychology, 78, 116-123.

Shell, D. F., Bruning, R. H., \& Colvin, C. (1995). Self-efficacy, attribution, and outcome expectancy mechanisms in reading and writing achievement: Grade-level and achievementlevel differences. Journal of Educational Psychology, 87(3), 386-398.

UNDP. (2013). Adult literacy rate, both sexes (age 15 and older). Retrieved from http:// hdr.undp.org/en/content/adult-literacy-rateboth-sexes-ages-15-and-older.
UNESCO Institute for Statistics (2015). Literacy data centre for regional and country profiles. Retrieved from http://www.uis.unesco.org/DataCentre/Pages/c ountry profile.aspx.code $=$ IDN \&regioncode $=40515$

Usaini, M. I., \& Abubakar, N. (2015).The influence of school environment on academic performance of secondary school students in Kuala Terengganu, Malaysia. Proceedings of ICIC2015 - International Conference on Empowering Islamic Civilization in the 21st Century e-ISBN: 978-967-13705-0-6.

Vacca, R. T., Vacca, J. L., \& Mraz, M. E. (2014). Content area reading: Literacy and learning across the curriculum (11 ${ }^{\text {th }}$ ed.). Boston, MA: Pearson Education.

Warncke, E. W., \& Shipman, D. A. (1984). Group assessment in reading: Classroom teacher's handbook. Englewood Cliffs, NJ: PrenticeHall, Inc.

Warwick, B. E. (1992). How in the World do students read? I.E.A. Study of Reading Literacy. Hamburg.

Widdowson, H. G. (1990). Aspects of Language Teaching. Oxford: Oxford University Press.

World's Most Literate Nations (WMLN) (2016). Education system input. Retrieved from http://www.ccsu.edu/wmln/educationSystem.ht $\mathrm{ml}$

Xu, J. (2009). School location, student achievement, and homework management reported by middle school students. The School Community Journal, 19(2), 27-43.

i Paper presented at AARE International Conference, Melbourne, 27 Nov - 1 Dec 2016 